childhood, the diagnosis of his illness and how he came to terms with it, and his attitudes towards science. I was surprised at the reasons he gives for having become a cosmologist. He says he had a need "to know how things worked and to control them. ... If you understand how the universe operates, you control it in a way." This emphasis on control, rather than on knowledge as an end in itself, is an attitude that disturbs many non-scientists. In a society increasingly aware of environmental issues, control of nature through science is often blamed for the destruction of the environment. To seek control of the whole Universe seems like the ultimate power game.

Without the snappy title or narrative thread of A Brief History, it is unlikely that this book will achieve the popularity of its predecessor. But that is not to say that sales will not be high. Even Hawking's highly technical graduate text on general relativity can now be found on the popular science shelves of some bookshops.

Felicity Mellor is in the Department of Physics, University of Sussex, Brighton BN1 9QH. UK.

\title{
Tapping into water tables
}

\section{Norman Myers}

Water in Crisis: A Guide to the World's Fresh Water Resources. Edited by Peter H. Gleick. Oxford Science Publications: 1993. Pp. 473. £40, \$55 (hbk); £19.50, $\$ 29.95$ (pbk).

IT has been said that food was the crisis of the 1970 s, energy of the 1980 s, and that water will prove to be the crisis of the $1990 \mathrm{~s}$. All that is wrong with this assertion is that food and energy continue to be crises. As for water, humans doubled their consumption between 1940 and 1980, and are likely to double it again by the year 2000 . Nothing to worry about of course if supplies are plentiful. But already two billion people, or almost every third person worldwide, suffer chronic water shortages.

There are severe water deficits in the Middle East, where oil is far from the most prized liquid resource and where a key factor in the peace negotiations lies with water supplies. (Israel, Jordan and the
West Bank plan to draw water from the River Jordan in amounts far beyond the river's flows.) There is acute competition for water in the fertile farmlands of the north China Plain, a region producing one-quarter of China's grain. In the United States, one-fifth of irrigated lands depend on excessive pumping of ground water, and the Ogallala Aquifer, the largest in the world, is being depleted at a rate scores of times that of natural replenishment. Within little more than 20 years, two-thirds of Africans are expected to experience 'water anaemia'.

The consequence of an ever more thirsty world is not only lack of water for agriculture, which accounts for two-thirds of our water use. It also translates into ill-health. A full 90 per cent of disease in the developing world is related to dirty water: most of the 40,000 children who die each day could be saved through better water supplies - with all that implies for motivation for family planning.

All the more welcome, then, is this book, edited by Peter Gleick, who is an expert in the field. It contains nine review papers on water in relation to health, agriculture, hydropower, fisheries and economic development generally. All are by leading specialists such as Malin Falkenmark, Stephen McCaffrey, Sandra Postel and Igor Shiklomanov as well as Gleick himself. But the bulk of the book is made up of 217 tables of data on water resources at global, regional and national levels; consumption patterns and trends; water-related diseases and sanitation; pollution of numerous sorts; irrigated agriculture; and water law, policies and politics.

These data constitute an information stock of exceptional value, by far the best I have ever encountered. How I wish such a compendious assembly of facts and figures had been available two decades ago - in which case political leaders and policy makers might have been better aware of the emergent problem and we might conceivably have had less of a water crisis today.

The book's editor is director of the Pacific Institute for Studies in Development, Environment, and Security, based in Oakland, California. The last item, security, is especially pertinent. Gleick demonstrates that friction over water supplies offers much potential for conflict. Of 214 major river basins, three-quarters are shared between two nations and a quarter between three to ten nations. Almost half of the Earth's land surface is located within international river basins, supporting 40 per cent of the world's population; and nearly 50 nations have more than three-quarters of their territory within such areas. Tensions and violence have already erupted in the river basin of the Mekong, which is shared between Laos, Thailand, Kampuchea and Vietnam; in that of the Amur, shared between China and the former Soviet Union; and in several other river systems of geostrategic value. Of the Indus River basin, vital to the world's largest irrigation network in Pakistan, two-fifths lie in India, a nation with which Pakistan maintains relations of armed confrontation.

The book is particularly timely in that the water crisis receives all too little attention. It was hardly mentioned in the Brundtland Report or at the Rio Earth Summit. We tend to take water for granted, even though it lies at the heart not only of all life but of the livelihoods of most people on Earth. When it rains in Britain, people pull a face, whereas in Africa they dance in the streets. Two billion people will use less water for all their household needs today than will readers of this journal each time they flush the lavatory.

Norman Myers is at Upper Meadow, Old Road, Headington, Oxford OX3 8SZ, UK. 